\title{
THE APPLICATION OF LABOUR LAW TO RELIGIOUS LEADERS IN SOUTH AFRICA
}

\author{
by Devon-Lee Andriés*
}

\section{Introduction}

This article falls upon the backdrop of a highly debated and controversial area of the law. In 2009 a homosexual minister was dismissed from her position at a Methodist church upon announcement of her impending marriage to her female partner. ${ }^{1}$ This opened up the pertinent question of whether such a person constitutes an employee for purposes of labour law, which is what this article seeks to address.

\section{Facts of the case and the unanswered question}

De Lange $v$ Presiding Bishop of the Methodist Church of Southern Africa for the Time Being ${ }^{2}$ involved a homosexual Methodist minister who had been living with her partner on church premises. ${ }^{3}$ Upon announcement of her intention to marry her partner, the church dismissed her. ${ }^{4}$ The church based this dismissal on the grounds that this was a breach of the church's policy and practices which only recognise heterosexual marriages. ${ }^{5}$

The court ended up dealing with an issue quite far from the direction in which it was anticipated the case would head. The Constitutional Court had to deal mostly with whether Mrs De Lange could appeal the Supreme Court of Appeal's judgment on the basis that the arbitration agreement, between her and the church, was not validly entered into or enforced. ${ }^{6}$ It was anticipated that the court would need to assess whether Mrs De Lange was an employee of the church and therefore entitled to rely on the laws governing unfair dismissal. Although the judgment focused on a different issue, it is

* $\quad$ Final year LLB student, University of Pretoria.

1 G Nicolaides 'Gay Reverend takes Appeal to ConCourt' http://ewn.co.za/2015/ 08/28/Gay-reverend-takes-appeal-to-ConCourt (accessed 16 October 2015).

22016 (2) SA 1 (CC).

3 De Lange (n 2 above) para 4.

4 De Lange (n 2 above) para 5.

5 As above.

6 De Lange (n 2 above) para 2. 
strongly believed that the facts of this case are an excellent example of the type of instance in which a religious leader may require the protection of South African labour law.

If Mrs De Lange were to qualify as an employee, she would be entitled to rely on the Employment Equity Act (hereafter the EEA) which denotes that dismissal based on sexual orientation is automatically unfair and invalid. ${ }^{7}$ However, on the other hand, if Mrs De Lange was not held to be an employee but rather a person providing services for the church on the basis of her spiritual calling, she would not be able to rely on such legislation. It seems in this instance, there would not be much protection for religious leaders. However, the question is whether this corresponds with the Constitutional provision that everyone is entitled to fair labour practices? $^{8}$

Olivier states that the decisive criterion in determining whether a minister of religion is an employee or not, is whether there was an intention to enter into a binding contractual arrangement and particularly, one with the nature of an employment relationship. ${ }^{9}$

\section{The legislative framework: Who is an employee?}

The Constitution, which is the supreme law of South Africa, entrenches the right to fair labour practices. ${ }^{10}$ Various pieces of legislation have been created to give effect to this constitutional right. These include the Labour Relations Act ${ }^{11}$ (hereafter the LRA), the EEA ${ }^{12}$ and the Basic Conditions of Employment Act $^{13}$ (hereafter the BCEA), to name a few.

Section $\mathbf{2 1 3}$ of the LRA defines an employee as:

(a) any person, excluding an independent contractor, who works for another person or for the State and who receives, or is entitled to receive, any remuneration; and

(b) any other person who in any manner assists in carrying on or conducting the business of an employer.

7 Sec 6 of the Employment Equity Act 55 of 1998.

8 Sec 23 of the Constitution of the Republic of South Africa, 1996 (the Constitution).

$9 M$ Olivier "Reflections on the essence of employment status" minister of religions, judges and magistrates' (2008) 1 Tydskrif vir die Suid-Afrikaanse Reg 4.

$10 \operatorname{Sec} 23$ of the Constitution.

11 The Labour Relations Act 66 of 1995.

12 The Employment Equity Act 55 of 1998.

13 The Basic Conditions of Employment Act 75 of 1997. 
The BCEA ${ }^{14}$ contains a definition identical to that of the LRA. While, the EEA ${ }^{15}$ contains a similar definition for the word employee which only differs in the fact that the exclusion of an independent contractor does not appear in subparagraph (a) but in the introductory paragraph.

Notwithstanding the definition of 'employee', provided for in the abovementioned legislation, the courts have struggled in deciding who constitutes an employee. The legislature has attempted to resolve this issue by including a deeming clause in Section 200A of the LRA, but uncertainty still looms in this regard. ${ }^{16}$

In assessing the above definition of 'employee', firstly, it is clear that a distinction is made between an employee and an independent contractor. This very distinction is the topic of much deliberation in case law. In Smit $v$ Workmen's Compensation Commissioner ${ }^{17}$ the court summarised a list of factors which indicate the difference between these two types of workers. ${ }^{18}$ These factors include the following: the type of work at hand - a personal service or a specified result; if the service is performed personally or through another; if the service is readily available or only performed for a specified period; if the worker is obliged to carry out the instructions of the employer or alternatively, if the worker is subservient to the provisions of a contract. ${ }^{19}$

The term 'works for' in subsection (a) includes a person who has concluded an employment contract but has not yet started working. ${ }^{20}$ This allows for a broader protection of vulnerable persons, which is the main aim of labour legislation. ${ }^{21}$ This interpretation of the definition of employee emphasises the importance of an employment contract. It is implied that, should an employment contract exist, from the date of conclusion, the parties are employer and employee respectively. 22

Subsection (b) of the definition expands the very narrow description of an employee provided in subsection (a). ${ }^{23}$ This assists in situations where a person may be engaged in an employment relationship with their employer whilst not having concluded a formal employment contract. ${ }^{24}$ 
More important than the definitions themselves, is the interpretation of the LRA. Section 3 of the LRA sets out guidelines on how to interpret the provisions of this Act. ${ }^{25}$

Any person applying this Act must interpret its provisions-

(a) to give effect to its primary objects;

(b) in compliance with the Constitution; and

(c) in compliance with the public international law obligations of the Republic.

Bearing this interpretation in mind, it is now necessary to asses one of the more important provisions used in employee identification.

Section 200A of the LRA reads as follows: ${ }^{26}$

(1) Until the contrary is proved, a person, who works for or renders services to any other person, is presumed, regardless of the form of the contract, to be an employee, if one or more of the following factors are present:

(a)The manner in which the person is subject to the control or direction of another person;

(b)The person's hours of work are subject to the control or direction of another person;

(c)In the case of a person who works for an organisation, the person forms part of that organisation;

(d)The person has worked for that other person for an average of at least 40 hours per month over the last three months;

(e)The person is economically dependent on the other person for whom he or she works or renders services;

(f) The person only works for or renders services to one person.

(2) Subsection (1) does not apply to any person who earns in excess of the amount determined by the minister in terms of Section 6(3) of the Basic Conditions of Employment Act.

(3) If a proposed or existing work arrangement involves persons who earn amounts equal to or below the amounts determined by the Minister in terms of section 6(3) of the Basic Conditions of Employment Act, any of the contracting parties may approach the Commission for an advisory award on whether the persons involved in the arrangement are employees.

(4) NEDLAC must prepare and issue a Code of Good Practice that sets out guidelines for determining whether persons, including those who earn in excess of the amount determined in subsection (2) are employees.

25 Sec 3 of the Labour Relations Act.

26 Sec 200A of the Labour Relations Act. 
This section was enacted in response to problems which arose from the identification of an employee. ${ }^{27}$ A person is deemed to be an employee if any one of the abovementioned criteria is satisfied, regardless of indications to the contrary. ${ }^{28}$ Section $200 \mathrm{~A}$ has created a rebuttable presumption which places a burden on the employer to prove that the worker is not an employee should any of the factors above be triggered. ${ }^{29}$ Section $200 \mathrm{~A}(2)$ explains that this rebuttable presumption does not apply to persons who are earning more than an amount specified by the Minister of Labour - which is currently fixed at R205 433, 30 per annum. ${ }^{30}$ Section $200 \mathrm{~A}(4)$ provides that persons earning more than the aforementioned amount, can look to a Code of Good Practice to determine their employment status.

This presumption gives rise to an easier way to categorise workers as employees or non-employees. This distinction is important for the application of employee protection, as mentioned above. However, this is not the only factor determining the status of working persons. Over and above black and white definitions, practice has turned to assessing the nature of the relationship between employers and their workers.

At common law, there is large emphasis placed on the existence of an employment contract being the indicator of a person qualifying as an employee. In more recent years, the focus has shifted from the importance of a contract to establishing whether an employment relationship exists. In the case of State Information Technology Agency (SITA) (Pty) Ltd $v \quad C C M A^{31}$ the court supported the aforementioned shift and emphasised that the existence of a valid employment contract does not carry as much weight as an enquiry into the existence of an employment relationship. ${ }^{32}$ The court went further than that and actually laid down criteria to determine the existence of such a relationship. ${ }^{33}$ This criteria includes assessing an employer's right to supervision and control, whether an employee forms an essential part of the organisation, and the extent of the economic dependence of the employee upon the employer. ${ }^{34}$ To further entrench this change of focus, all reference to 'contract of employment' in the definition in the Labour Relations Amendment $\mathrm{Act}^{35}$ has been removed. ${ }^{36}$ This alteration allows for a wide scope of

27 Du Toit (n 20 above) 93.

28 Grogan (n 16 above) 17.

29 Du Toit (n 20 above) 93.

30 Van Niekerk (n 18 above) 63.

312008 (7) BLLR 611 (LAC).

32 Van Niekerk (n 18 above) 63.

33 State Information Technology Agency (SITA) (Pty) Ltd (n 31 above) para 12.

34 Van Niekerk (n 18 above) 63.

35 Labour Relations Amendment Act 6 of 2014

36 Du Toit (n 20 above) 89. 
application of protection for any person engaged in an employment relationship. 37

In the case of Discovery Health Ltd $v C C M A^{38}$ it was held that 'a contract of employment is not the sole ticket for admission into the golden circle reserved for employees'. ${ }^{39}$ It is therefore clear that a valid and enforceable contract of employment is not a pre-requisite for workers to obtain rights in terms of the LRA. ${ }^{40}$ This broad scope must not, however, allow for an employment relationship to be inferred without the parties having intended such a relationship to come into existence. ${ }^{41}$

It should be borne in mind that in addition to the applicable legislation discussed above, the intention of the parties is of vital importance. It was so eloquently stated by Olivier: 'It is clear that the written contract and the intentions/perceptions of the parties are extremely important, although not conclusive: the true nature of the relationship and the conduct of the parties can still point to an opposite conclusion.' 42

If we are to look specifically at the presumption of employment set out above, on a very basic level, the following thoughts come to mind regarding the manner of control to which a person is subject. ${ }^{43}$ It can be argued that a religious leader is subject to the control of God and not necessarily to that of the church. It is opined that this places a religious leader within the spiritual realm of work as opposed to the commercial sphere. This would result in a religious leader not qualifying as an employee, but rather a servant, not of the church, but of God.

Secondly, regarding economic dependence of a person, ${ }^{44}$ it is fairly clear that a religious leader would rely financially on the church, however what is found to be very important in this argument is that monetary security is not the goal of a religious leader. This is in contrast to people in, for instance, an administrative job, where remuneration forms a large part of their purpose and motivation for fulfilling such a role. However, the perception is that religious leaders reap their reward through the doing of good deeds and fulfilling their God-given spiritual purpose. A monetary sentiment is merely a bonus. Although this financial reward is vital to the day-to-day wellbeing of a religious leader and their family, this does not seem to be the foundation upon which the office of a religious leader is fulfilled.

37 As above.

382008 (7) BLLR 633 (LC).

39 Discovery Health Ltd (n 38 above) para 49.

40 Du Toit (n 20 above) 89.

41 Du Toit (n 20 above) 90.

42 Olivier (n 9 above) 3.

43 Sec 200A(1)(a) of the Labour Relations Act.

$44 \operatorname{Sec} 200 \mathrm{~A}(1)(\mathrm{e})$ of the Labour Relations Act. 
These two points are indicative of the fact that an employment relationship is created through the presence of an intention to do so. Furthermore, the motive of both parties regarding the purpose of the agreement is also decisive.

Olivier's statement above and the law surrounding this issue implies that while specific tests, presumptions and legislation may appear to indicate one thing, the nature of the relationship and the intention of the parties may indicate the contrary. 'An employment relationship cannot be forced upon parties who did not intend one.' 45 The type of relationship formed is decisive in this matter over any other indication, including rigid parameters set out in legislation.

\section{The Court's Stance}

The Labour Appeal Court held in the case of Universal Church of the Kingdom of God v Myeni ${ }^{46}$ that a minister was not an employee and that section $200 \mathrm{~A}$ did not apply. ${ }^{47}$ The court referred to the UK case of President of the Methodist Conference $v$ Preston ${ }^{48}$ where Lord Sumption stated 'the question whether an arrangement is a legally binding contract depends on the intentions of the parties. ${ }^{49}$ In the recent case of Universal Church of the Kingdom of God $v$ Myeni ${ }^{50}$ the court assessed section 200A in the context of a religious leader. The court held that 'section 200A advocates substance over form' and that a proper construction of this section requires a legally enforceable agreement or working arrangement between the parties. ${ }^{51}$ This necessitates a contract of employment as a prerequisite for section $200 \mathrm{~A}$ to apply, according to Ndlovu JA of the Labour Appeal Court.

In the case of Schreuder $v$ Nederduitse Gereformeerde Kerk, Wilgespruit \& others ${ }^{52}$ (the Schreuder case) a priest was dismissed by a church and when the priest contended this dismissal was unfair, the court had to determine whether the priest was in fact an employee. ${ }^{53}$ The court held that the priest was an employee due to the letter of appointment issued by the church. ${ }^{54}$ It was held that this letter created contractual obligations and therefore an employment relationship had arisen. 55

Olivier (n 9 above) 2.

2015 (36) ILJ 2832 (LAC).

Universal Church of the Kingdom of God (n 46 above) para 49.

(2013) UKSC 29.

n 48 above, para 26.

n 46 above.

Universal Church of the Kingdom of God (n 46 above) paras $37 \& 40$.

(20) ILJ 1936 (LC).

The facts as set out in B Grant 'Is a priest an employee for the purposes of our labour legislation’ (2003) 24 Obiter 158.

As above

Schreuder (n 52 above) para 19. 
The court took an opposite view in the case of Church of the Province of Southern Africa Diocese of Cape Town v CCMA \& others ${ }^{56}$ (the Church Diocese case) where a minister was dismissed on two charges of misconduct. ${ }^{57}$ The minister approached the CCMA stating that this dismissal was unfair and that he should be afforded protection as an employee of the church. ${ }^{58}$ The court held that the priest was not an employee for purposes of labour law. ${ }^{59}$ The court was concerned with the type of relationship between a priest and the church. It was held in the Church Diocese case that the very basis of the relationship between the church and the priest is the priest's 'calling from God. ${ }^{60}$ The church merely provides a platform upon which the priest is able to give effect to this calling. The court held that while this space may happen to provide all the features of an employment relationship, this does not make such a relationship an employment one ${ }^{61}$ The court further emphasised the importance of assessing the intention of the parties: 'offer, acceptance and consideration must be accompanied by an intention to create a contractible relationship giving rise to enforceable obligations' ${ }^{62}$ Calitz so eloquently states: ${ }^{3}$

In the light of the perceived special calling of a priest, he will not be regarded as an employee of the church unless it is clear that there was indeed an intention to create such a relationship.

In a journal article detailing the very same question being discussed, Grant reconciles the two vastly different views held in the Schreuder and Church Diocese cases. Grant believes the correct approach was adopted in the Church Diocese case where the court focused on the intention of the parties. ${ }^{64}$ Grant explains that in asking whether a priest is an employee or not, one cannot ignore the basis of the relationship, which in this instance, is a calling from God. ${ }^{65}$ This renders the relationship ecclesiastical in nature as opposed to contractual. ${ }^{66}$ It has been said that although there may be an

56 Church of the Province of Southern Africa Diocese of Cape Town v CCMA 2002 (3) SA 385 (LC).

57 Church of the Province of Southern Africa Diocese of Cape Town (n 56 above) para 3.

58 Church of the Province of Southern Africa Diocese of Cape Town (n 56 above) para 4.

59 Church of the Province of Southern Africa Diocese of Cape Town (n 56 above) para 40.

60 Church of the Province of Southern Africa Diocese of Cape Town (n 56 above) para 37.

61 As above.

62 Church of the Province of Southern Africa Diocese of Cape Town (n 56 above) para 33.

63 K Calitz 'The Liability of Churches for the Historical Sexual Assault of Children by Priests’ (2014) Potchefstroom Electronic Law Journal (17) 2461.

64 Grant (n 53 above) 160.

65 Grant (n 53 above) 161.

66 Grant (n 53 above) 162. 
agreement to certain obligations between a church and a priest, this agreement flows more from a spiritual sphere than an enforceable civil contract. ${ }^{67}$ In the case of Smith $v$ Die Ring van Amandelboom van die Verenigde Gereformeerde Kerk in Suider Afrika (VGKSA) ${ }^{68}$ the court found that the minister was subject to the authority and discipline of the church but that such authority and discipline arose from an ecclesiastical authority of the church and not an employment relationship between the parties. ${ }^{69}$

Other perspectives provide that ministers or members of the clergy can indeed be appointed as an employee. ${ }^{70}$ In the case of Wagenaar $v$ Uniting Reformed Church in $S A^{71}$ the court found that the parties had made a conscious effort to comply with labour legislation and that the parties intended for such legislation to be applicable. ${ }^{72}$ Consequently, the court found that the church constitution was supplementary, and did not replace the labour legislation. ${ }^{73}$

In the case of Borcherds $v C W$ Pearce \& $F$ Sheward t/a Lubrite Distributors, ${ }^{74}$ where the facts did not deal with a religious minister, but still with the question of identifying an employee, the court held that the applicant was not an employee due to him being his own master and not bound by his employer's orders. ${ }^{75}$ In applying this to the above unanswered question, one could argue that priests are more subjected to the orders of God than that of the church since their primary objective is to fulfil the will of God. This would mean that an element of control by the church over a religious leader would be diminished. Ultimately this issue comes down to the question of whether a religious leader is a 'servant of man or a servant of God.'76

Case law dictates that the intention of the parties is of the utmost importance. Did they intend to enter into an agreement, in the nature of an employment relationship which gives rise to legally binding obligations? ${ }^{77}$ Giving power to the intention of the parties reiterates one of the cornerstones of the law of contract, namely, the freedom of contract. This principle plays a vital role in our law and should not be overlooked. In stating that the intention of the parties is important, cognisance is taken of the fact that ascertaining such an intention may be difficult due to the spiritual calling upon which a religious leader commences their job. Perhaps some form of

67 Olivier (n 9 above) 4

68 Case no NHK11/2/5587 (unreported).

69 Smith (n 68 above) para 22-23.

70 Olivier (n 9 above) 6

712005 (1) BALR 127 (CCMA).

72 Wagenaar (n 71 above) paras 133 F-H \& 134 F-G.

73 Wagenaar ( $\mathrm{n} 71$ above) paras $133 \mathrm{H}-\mathrm{I}$.

741991 (12) ILJ 383 (IC).

75 Borcherds (n 74 above) para 386A.

76 As stated by J Hawthorne in “"Priests" employment rights: Your service or His?" http://www.economist.com/node/21538148 (accessed 31 May 2016).

77 Olivier (n 9 above) 14 
regulation would assist in ascertaining and appropriately dealing with the intentions of the parties in this situation. This results in one having to assess this question on a case by case basis. It may not be adequate to have hard and fast rule as to whether religious leaders are employees or not.

\section{An International Perspective}

The international labour community plays an enormous role in the implementation of South Africa's labour laws. It is entrenched in our Constitution that when interpreting any legislation, courts should prefer an interpretation consistent with international law, as opposed to an inconsistent interpretation. ${ }^{78}$ In assessing whether religious leaders qualify as employees, we should also assess the legal jurisprudence of our international counterparts, those who are also member states to the ILO, namely the United Kingdom (hereafter UK) and Australia. 79

Labour law in the UK is regulated by various pieces of legislation. One of the more pertinent legislative instruments is the Employment Rights Act (hereafter the ERA). ${ }^{80}$ This Act defines 'employment status' in the following way: ${ }^{81}$

(1) In this Act "employee" means an individual who has entered into or works under (or, where the employment has ceased, worked under) a contract of employment.

(2) In this Act "contract of employment" means a contract of service or apprenticeship, whether express or implied, and (if it is express) whether oral or in writing.

(3) In this Act "worker" (except in the phrases "shop worker" and "betting worker") means an individual who has entered into or works under (or, where the employment has ceased, worked under)-

(a) a contract of employment, or

(b) any other contract, whether express or implied and (if it is express) whether oral or in writing, whereby the individual undertakes to do or perform personally any work or services for another party to the contract whose status is not by virtue of the contract that of a client or customer of any profession or business undertaking carried on by the individual;

and any reference to a worker's contract shall be construed accordingly.

78 Sec 233 of the Constitution.

79 International Labour Organisation 'ILO Standards' http://www.ilo.org/public/ english/standards/realm/country.htm (accessed 10 April 2016).

80 Ch 18 of the Employment Rights Act 1996.

81 Sec 230 of the Employment Rights Act 1996, ch 18. 
(4) In this Act "employer", in relation to an employee or a worker, means the person by whom the employee or worker is (or, where the employment has ceased, was) employed.

(5) In this Act "employment"-

(a) in relation to an employee, means (except for the purposes of section 171) employment under a contract of employment, and

(b) in relation to a worker, means employment under his contract; and "employed" shall be construed accordingly.

In interpreting the above provision regarding employment status, it is clear that there are three types of employment under which an individual may fall, namely an employee; and independent contractor and a worker. ${ }^{82}$ Davies states that this definition of employment status portrays a contract of employment as a common law concept ${ }^{83}$ which leads to much litigation 'as individuals strive to get into a more protected category and employers seek to avoid the legal obligations that would follow from this, 84

There are a variety of tests that have been developed over the years in UK law dealing with the determination of employment status. Firstly, the control test was applied in the case of Yewens $v$ Noakes ${ }^{85}$ where the court explained the 'master-servant' nature of the employment relationship. In this type of relationship an employer has the ability to not only control the work the employee performs, but also the manner in which it is performed. 86 This test has been criticised as being vague and although it is a common sense approach, these criteria often fail in the face of more complex labour constructions. 87

Secondly, the organisation test was used in the case of Cassidy $v$ Ministry of Health. ${ }^{88}$ This test made the consideration of the part played by an individual in the employer's organisation more important than the degree of control to which such an individual was subjected. ${ }^{89}$ The organisation test was viewed in a more favourable light than the control test. ${ }^{90}$

In the case of Ready-Mixed Concrete (South East) Ltd v Minister of Pensions and National Insurance ${ }^{91}$ the court laid down three tests Issues para 4.

83 A Davies Perspectives on labour law (2009) 81

84 Davies (n 83 above) 91.

85 (1880) 6 QBD 530.

86 As discussed in Yewens $v$ Noakes (n 85 above).

87 O Kahn-Freund 'Servants and independent contractors' (1951) 14 The Modern Law Review 507.

88 (1951) 2 KB 343.

89 As discussed in Cassidy (n 88 above).

90 Marson (n 82 above) para 5.

91 (1968) 2 QB 497. 
to determine employment status. This is the more modern test used in the UK. ${ }^{92}$ These tests were posed as questions, namely: ${ }^{93}$

(1) The servant agrees that, in consideration of a wage or other remuneration, he will provide his own work and skill in the performance of some service for his master;

(2) He agrees, expressly or impliedly, that in the performance of that service he will be subject to the other's control in a sufficient degree to make that other master; and

(3) The other provisions of the contract are consistent with it being a contract of service.

The abovementioned tests, developed and applied by courts create a checklist which is to be applied in proving a prima facie case of employment status. ${ }^{94}$

Despite the tests available to the courts in the UK, often it is still difficult to determine what the outcome would be of, for example, a question like: do religious leaders qualify as employees? There is a long line of English cases which consistently held that ministers serve the church in terms of ecclesiastical law. ${ }^{95}$ There appear to be two vital cases which came before the UK courts dealing with this very question, namely: Percy $v$ Church of Scotland Boards of National Mission $^{96}$ (the Percy case) and New Testament Church of God $v$ Stewart ${ }^{97}$ (the Stewart case).

In the Percy case, the court was faced with determining whether a minister's relationship with the church constitutes one of employment. ${ }^{98}$ The court paid special attention to whether legal relations were intended in the appointment of Ms. Percy as a minister. There initially seems to be a presumption created against the intention to create legal obligations. ${ }^{99}$ Lord Nicholls of Birkenhead expressed the opinion that employment arrangements between a minister and a church should be easily assumed to have no legal effect. ${ }^{100}$ The House of Lords held, in this case, that the minister was a 'worker' as defined in section 230(3) of the ERA. ${ }^{101}$

The Court of Appeal took a different stance in the Stewart case and held that the minister was an employee in terms of section 230(1)

92 Marson (n 82 above) para 5.

93 Ready-Mixed Concrete (South East) Ltd (n 91 above) para 499.

94 Marson (n 82 above) para 7.

95 Calitz (n 63 above) 2455.

96 (2005) UKHL 73.

97 (2007) IRLR 178 EAT.

98 Percy (n 96 above) para 1

99 Percy (n 96 above) para 23.

100 Percy (n 96 above) para 26.

101 J Duddington 'God, Caesar and the employment rights of ministers of religion' (2007) 159 Law \& Justice 129. 
of the ERA. ${ }^{102}$ Employee status provides the minister with a wider range of protection than that of a worker. ${ }^{103}$

Therefore, courts following the Percy judgement would not allow as wide a variety of claims based on labour law to ministers as they would, were they to follow the Stewart judgement. Workers in terms of UK law are provided less protection that those with employment status. This conflict would result in a lack of legal certainty.

Duddington, in a journal article titled 'God, Caesar and the employment rights of ministers of religion' aims to show that there is no general principle affording religious leaders employment status. ${ }^{104}$ In doing so, Duddington discusses the impact of the European Convention on Human Rights (hereafter the ECHR). ${ }^{105}$ It should be noted that the UK's membership of the European Union (hereafter the EU) has initiated many protective mechanisms for those with employment status. ${ }^{106}$ However, despite the legal stance of the EU, the domestic law of the UK and the interpretation thereof is of supreme importance. ${ }^{107}$ In the case of Diocese of Southwalk $v$ Coker $^{108}$ the court found that a minister was not an employee firstly due to the lack of an employment contract but secondly due to the ecclesiastical office held by the clergyman. It was stated that such an office should be governed by ecclesiastical law. ${ }^{109}$

Straughton LJ, in the majority judgment of In re National Insurance Act 1911: In re Employment of Church of England Curates $^{110}$ held: 'one can say that a minister of religion serves God and serves his congregation, but does not serve an employer.'111 In agreement with this stance, The House of Lords in Davies $v$ Presbyterian Church of Wales ${ }^{112}$ held that a pastor's 'duties are defined and his activities dictated not by contract but by conscience... he is the servant of God.'113

Of all the cases discussed above, save for the Stewart case, it seems the UK courts prefer the stance that a pastor is not an employee for purposes of Labour law but is rather a servant of God held in his office by ecclesiastical/spiritual laws. It is evident that there is no set-in-stone rule for the status of religious leaders in terms

102 As above.

103 As above.

104 As above.

105 As above.

106 Marson (n 82 above) para 3.

107 As above.

108 (1998) ICR 140 (CA).

109 Diocese of Southwalk (n 108 above) as discussed in Church of the Province of Southern Africa Diocese of Cape Town (n 56 above) para 15.

110 (1912) 2 Ch. 563.

111 In re National Insurance Act 1911 (n 110 above) paras 150E - 151B.

112 (1986) 1 All ER 705 (HL).

113 Davies (n 112 above) paras 709g - j. 
of employment law. At this point, what does seem clear though, is that it is possible for religious leaders to be afforded protection in labour law in the UK. Perhaps this position can assist in deciding whether or not clergy should be afforded protection in terms of South African labour law.

In Australia, the main legislative guideline is the Workplace Relations Act. ${ }^{114}$ The principle aim of this Act is to provide a legal framework for 'cooperative workplace relations which promotes the economic prosperity and welfare of the people of Australia ..., 115 This Act defines an employee as: 116

an individual so far as he or she is employed, or usually employed, as described in the definition of employer in subsection 6(1), by an employer, except on a vocational placement.

An employer is defined as: ${ }^{117}$

(a) a constitutional corporation, so far as it employs, or usually employs, an individual; or

(b) the Commonwealth, so far as it employs, or usually employs, an individual; or

(c) a Commonwealth authority, so far as it employs, or usually employs, an individual; or

(d) a person or entity (which may be an unincorporated club) so far as the person or entity, in connection with constitutional trade or commerce, employs, or usually employs, an individual as:

(i) a flight crew officer; or

(ii) a maritime employee; or

(iii) a waterside worker; or

(e) a body corporate incorporated in a Territory, so far as the body employs, or usually employs, an individual; or

(f) a person or entity (which may be an unincorporated club) that carries on an activity (whether of a commercial, governmental or other nature) in a Territory in Australia, so far as the person or entity employs, or usually employs, an individual in connection with the activity carried on in the Territory.

Despite these lengthy definitions, there is still often confusion as to who qualifies as an employee in Australian labour law. For this, there is a common law test to distinguish between employees and independent contractors. According to L\&E Global in their publication

114 The Workplace Relations Act 1996.

115 Sec 3 of the Workplace Relations Act 1996.

116 Sec 5(1) of the Workplace Relations Act 1996.

117 Sec 6(1) of the Workplace Relations Act 1996. 
entitled 'Employees vs Independent Contractors', the multi-factor test is a guiding principle in making this distinction. ${ }^{118}$

In an Australian case; Knowles v Anglican Church Property Trust, Diocese of Bathurst, ${ }^{119}$ the court was faced with a case concerning an unfair dismissal of a priest of the Anglican Church. The judge held that the relationship between the priest and the church was a religious one, 'based on a consensual compact to which the parties were bound by their shared faith, based on spiritual and religious ideas, and not based on common law contract.' 120

The Supreme Court of South Australia was faced with a similar issue in the case of Greek Orthodox Community of South Australia v Ermogenous. ${ }^{121}$ The court focused on whether or not, with regard to religious leaders, there was a presumption of an intention to enter into contractual relations and the court answered this question in the negative. ${ }^{122}$ The court took note of the spiritual nature of the relationship between the parties as well as the ecclesiastical purpose to which a priest is subject. ${ }^{123}$ The court further discussed that determining whether the parties entered into an employment contract should be done with regard to the circumstances surrounding the relationship between the parties. ${ }^{124}$ The court further stated the following: ${ }^{125}$

No general principle will be established in this case for cases involving a contractual relationship between a minister of religion and a church or an entity that in some way retains a minister to exercise his or her ministry.

The court did eventually hold that the bishop was an employee of the church, after assessing the facts very closely. This case is a vital case in Australian labour law and it seems the outcome is that there is no presumption or general rule that a contract of employment is to be created, but rather that each case is decided on its own merits, taking into account the circumstances surrounding the situation.

Although these two cases may not totally be in agreement, what is clear is that there is no black and white conclusion in situations such as these. The court in Australian labour law has the discretion to decide whether or not a religious leader is an employee or not. This

118 L\&E Global 'Employees vs independent contractors: Understanding the distinction between contractors and employees and the re-characterization of a contractor into an employee' An L\&E Annual Publication.

119 (1999) 89 IR 47.

120 Knowles (n 119 above) 90.

12199 - 653 (2000) SASC 329.

122 Greek Orthodox Community of South Australia (n 121 above) para 4.

123 Greek Orthodox Community of South Australia (n 121 above) as discussed in Church of the Province of Southern Africa Diocese of Cape Town (n 56 above) para 22.

124 Greek Orthodox Community of South Australia (n 121 above) para 40.

125 Greek Orthodox Community of South Australia (n 121 above) para 9. 
decision is made after careful consideration of the nature of the relationship between the parties, which differs from case to case. This appears to be the deciding factor.

It is clear that in both the UK and Australia, there does not seem to be a clear-cut rule regarding the employment status, if any, of clergy. To further entrench the lack of general principles at hand, it seems that the surrounding circumstances of each case play a decisive role in determining employment status. This position may lead to legal uncertainty but until a solid set of principles which is applicable across the board is implemented, this will remain the legal standpoint.

What is overwhelmingly clear though, throughout the exploration of both countries' law, is that there is no general presumption that a contractual relationship exists between a priest and the church. Perhaps we can conclude that one would always need to provide evidence to this effect for the court to make such a finding. Interestingly, this is in direct contrast with the position in South Africa where there is a presumption of employment and one should try to disprove such a fact. One could go so far as to say that the default position in countries such as the UK and Australia is that religious leaders are not employees unless this is proven. However, in South Africa, on the basis of the aforementioned presumption, ${ }^{126}$ it seems the default position may lean more toward clergy occupying an employment status. It is opined that perhaps a presumption against legal obligations should be created in South Africa in instances involving clergy. This may also allow for more self-regulation of churches as a legal framework will not automatically apply.

Furthermore, the golden thread through the jurisprudence of the UK and Australia is that the court will make a decision on the question at hand based on the merits of the case and the surrounding circumstances.

\section{Conclusion}

Determining the status of religious leaders in labour law is vital due to the protection afforded to persons with employment status. It is appreciated that should religious leaders not be categorised as employees, they will not have access to the protection against, for example, unfair discrimination. However, if clergy were to have such protection, this would result in the courts having the power to intervene in the life and functioning of the church. The doctrine of entanglement strongly advises against courts being involved in issues 
of religious doctrine, ${ }^{127}$ as such interference may burden the right to religious freedom as entrenched in the Constitution. ${ }^{128}$

It has been stated that the intention of the parties is pertinent in determining the status of each person involved. In the case of clergy, the overwhelming intention seems to be to serve God and fulfil the ecclesiastical calling to do so. This intention does not indicate a strong willingness to regulate such a situation with a legal framework. According to this deduction, it seems that the default position of the UK and Australia as discussed above may be suitable to the South African labour jurisprudence. This denotes that there is a general presumption against legal obligations arising between a church and a religious leader.

It is found more appropriate for religious leaders not to qualify as employees but to be governed by some law specifically created for their very unique positions. This could perhaps be a piece of legislation, which provides for regulation of employment-typematters, but to be dealt with by the church internally and which gears away from the courts' involvement in such matters.

It is proposed that this legislation provides room for the policies and practices of the church, specific, of course to the religion at hand. This would allow churches to enforce these policies and practices upon religious leaders. Should a problem arise, these leaders would be able to rely on legislation providing for an internal remedy within the church. This protects job security which is not the main aim of religious leaders but is an inevitable consequence which impacts their and their dependent's lives.

Ultimately, law and religion are two indispensable elements of life in South Africa. It is my hope that the two will develop in the most positive light when they meet and operate as one.

127 De Lange (n 2 above) para 24

$128 \mathrm{Sec} 15$ of the Constitution. 